\title{
Evaluating the influence of different water sources on water quality, survival and growth rates of Nile tilapia (Oreochomis niloticus) larvae in tilapia hatcheries.
}

\section{Ahmed A. A. Ali²; Yasser T.A. Moustafa ${ }^{1 *}$; Soha M. Ahmed ${ }^{2}$}

1- Fish physiology and hatchery department; 2- Limnology department, Central Laboratory for Aquaculture Research (CLAR), Agricultural Research Center (ARC).

*ymoustafaonline@yahoo.com

Received: March 11, 2020; Accepted: March. 29, 2020 published: 2020 Vol.10 (1):45-64

\section{Abstract}

This study was conducted to evaluate the effect of different water sources on survival rate and growth performance of Nile tilapia ( $O$. niloticus) larvae during nursing period. Larvae (post yolk sac stage) were stocked at 50000 / pond and fed $48 \%$ crude protein diet 6 times daily at rates of 35,26 and $18 \%$ of their weight in the successive three weeks, respectively. Nine concrete ponds assigned for 3 treatments, triplicates in each. The ground water and agricultural drainage water were the water sources in the first and third treatments, respectively, while the second treatment received a 1: 1 mixture of the two water sources. Water samples, for some physico-chemical analysis, were monitored before pumping water into the ponds and within the ponds at each fry harvest. The experiment lasted for 21 days and replicated four times. At the end of each rearing period, fry number was estimated in each pond; the survival and growth rates were calculated.

The results showed that the significantly highest survival and growth rates were obtained in the mixed water treatment. Mixing agricultural drainage water with ground water results the most suitable water quality for Nile tilapia performance than each of these sources separately. Generally, water quality parameters for the studied sources at the end of each rearing period were within the acceptable range for fish culture. 
Keywords: Nile tilapia larvae, nursing period, water quality parameters, Oreochromis niloticus, Agricultural drainage water, ground water.

\section{INTRODUCTION}

Fish aquaculture is an eminent industrial activity in Egypt that contributes with about $80 \%$ of the total fish production in 2017 (GAFRD, 2017). Nile tilapia is the intrinsic cultured species followed by mullets and catfish. There is a real need for aquaculture expansion as the population grows and the demand on fish increase. However, water quality is considered a cardinal factor controlling the state of growth performance, health, disease outbreak among farmed fishes and subsequently expansion of aquaculture.

Poor water chemistry usually exacerbates stress, poor fish feed conversion efficiency disease outbreak and, ultimately death (Barker $\boldsymbol{e t}$ al., 2009; Swann 2010). Water quality is initially related to the source of the water. Well water may be low in dissolved oxygen and high in ammonia (Wyk and Scarpa 1999). However, groundwater is considered as the most desirable source of supply for aquaculture because it has more consistent diurnal and seasonal physico-chemical parameters than surface water, and much less likely to be contaminated by pathogens (Raju et al., 2014). Ground water obtained from deep wells or springs is the best source of water for fish culture. It generally is free of pollutants and has relatively high hardness levels, which are beneficial under some circumstances (Helfrich and Libey 2015). Thus, selecting a good source of water that will provide adequate quantities of water with suitablequality is one of the fundamental steps that determines to a great extent the success or failure of a fish cultural operation (Piper et al., 1982).

Chemical properties of water that are important to fish production and growth include total hardness, total alkalinity, and different forms of nitrogen and phosphorus, (Mmochi et al., 2002; Viadero 2005).

The importance of total hardness refers to its ability to reduce the toxicity of some heavy metals to freshwater fish. Pascoe $\boldsymbol{e t}$ al. (1986) and Linbo et al. (2009) found that the acutely lethal toxicity of cadmium and copper to fish and other aquatic organisms is reduced by high water hardness as a result of formatting insoluble complexes. Chapman and Dunlop (1981) recommended treating effluents from lead and zinc workings with calcium in order to protect freshwater fish, crustacean and protozoan. Moreover, Fleischman et al. (1968) noted increased faecal excretion of cadmium in mammals maintained on high calcium diets. 
Heath (1987) and Meade (1989) noted positive effects on fish health of waters with hardness in excess of $\sim 400 \mathrm{mg} / \mathrm{l}$ as $\mathrm{CaCO}_{3}$. However, WHO (2003) and Khan et al., (2017) recommended 50-100 $\mathrm{CaCO}_{3} \mathrm{mg} / \mathrm{l}$ level of water hardness for fish farming. Concentrations above $200 \mathrm{mg}$ $\mathrm{CaCO}_{3} / \mathrm{l}$ are acceptable for aquaculture activity (Boyd 1998). Zaki (2014) reported that the permissible range of total hardness is between 190 and $214 \mathrm{mg} / \mathrm{l}$ for Nile tilapia.

Total alkalinity is mainly derived from the dissociation of $\mathrm{CaCO}_{3}$ and $\mathrm{CaHCO}_{3}$ and is consequently, directly related to water hardness. Generally, total hardness was consistently greater in concentration than total alkalinity. This is a common phenomenon in aquaculture ponds (Boyd and Tucker, 1998). A low alkalinity and high hardness may also occur in acidic well or surface waters (Wyk and Scarpa 1999). Nevertheless, Boyd (1998) stated that well water may have total alkalinity much higher than total hardness. Wurst and Duborrow (1992) and Boyd (1998) reported that total alkalinity higher than $20 \mathrm{mg} / \mathrm{l}$ is necessitate for good productivity in fish ponds, and the desirable total alkalinity range for aquaculture is between 75 and $200 \mathrm{mg} / \mathrm{l}$. Zaki (2014) reported that the permissible range of total alkalinity for Nile tilapia is $208-233 \mathrm{mg} / \mathrm{l}$. It is reported that increasing total alkalinity up to least 150 $\mathrm{mg} / \mathrm{l}$ results in an increase of pond water fertility (Boyd 1998).

Alkalinity importance is partially attributed to reducing the toxicity of some heavy metals as well as contributing in nitrification process. Linbo et al. (2009) confirmed that water alkalinity at a level of $250 \mathrm{mg} / \mathrm{l}$ as $\mathrm{CaCO}_{3}$ reduced the toxicity of copper. Autotrophic bacteria is reported to utilize inorganic carbon, mainly from alkalinity, and realize the nitrification process in two steps (Burton \& Prosser 2001; Chen et al., 2012). Viadero (2005) showed that low alkalinities generally contribute to fish stress when elevated concentrations of $\mathrm{CO}_{2}$ and a weak acid, often found in ground water, are exist. Cavalcante et al. (2012) demonstrated improvement in Nile tilapia growth when hardness : alkalinity ratio is maintained equal or superior to 1 .

Water chemistry can also have an impact on ammonia toxicity. It has been reported that increased divalent cation concentrations may reduce the toxicity of $\mathrm{NH}_{3}-\mathrm{N}$ by altering the osmoregulatory systems of fish and decreasing membrane permeability (Potts and Fleming. 1970). The ammonium is oxidized to nitrite and after to nitrate, which is a less toxic nitrogen compound (Burton \& Prosser, 2001). 
Nitrite $\left(\mathrm{NO}_{2}^{-}\right)$is produced through the biochemically mediated oxidation of ammonia-nitrogen by Nitrosomonas sp. Thus as a rule, nitrite is found together with nitrates and ammonia nitrogen but its concentrations are usually low because of its instability (Svobodová et al., 1993). Nitrite concentrations in excess of $0.55 \mathrm{mg} / \mathrm{L}$ can result in methemoglobinemia, a condition in which the iron in blood cannot transport oxygen. As a consequence, oxygen uptake by fish becomes limited (Viadero 2005). Methemoglobin can be seen as a brown colour of the blood and gills. Nevertheless, methaemoglobin can be converted to haemoglobin again through enzyme reductase within the fish body within 24-48 hours, if the fish are put into nitrite-free water (Yildiz et al., 2006). Long exposure to sublethal concentrations of nitrites does not cause much damage to the fish (Svobodová et al., 1993).

Lewis and Morris (1986) have shown that nitrite toxicity to fish can be affected by certain water quality characteristics. Nitrite toxicity can be influenced by bicarbonate, potassium, sodium, calcium and other ions. Chen et al. (2012) reported that the alkalinity influences the nitrification process, where there is a strong effect of inorganic $\mathrm{C}$ concentration on the oxidation of ammonia to nitrite.

The monitoring of $\mathrm{NO}_{3}{ }^{-}-\mathrm{N}$ and $\mathrm{PO}_{4}{ }^{-} \mathrm{P}$ water levels in aquaculture systems is fundamental, where they could be considered indicators for reuse as well as for correct discharge as effluent (Martins $\boldsymbol{e t}$ al., 2019). The main sources of nitrate pollution of surface waters are the use of nitrogenous fertilizers and manures (Svobodová et al., 1993), which explain why nitrate may be high in agricultural drainage water. The toxicity of nitrates to fish is very low, and mortalities have only been recorded when concentrations have exceeded $1000 \mathrm{mg} \mathrm{l}^{-1}$. The the maximum admissible nitrate concentration for carp is $80 \mathrm{mg} \mathrm{l}^{-1}$ while 20 $\mathrm{mg} \mathrm{l}^{-1}$ is for rainbow trout (Svobodová et al., 1993). Monsees et al. (2017) reported that nitrate values below $500 \mathrm{mg} / \mathrm{l}$ ensure the optimum growth and health to Nile tilapia.

On the light of decrease of freshwater in Egypt at the current period and foreseen more decrease in the near future we have to search for alternative water sources for aquaculture industry. Hence, the health and subsequent growth of fish is directly related to the quality of water in which the fish are raised. Therefore, these water sources should have basic quality parameters that render it suitable for aquaculture. 
Thus the present study was designed to investigate the potentiality of using different water sources for incubating larvae of Nile tilapia and their influence on the survival and growth performance.

\section{MATERIALS and METHODS}

The present study was conducted in Nile tilapia (O. niloticus) hatchery at the Central Laboratory for Aquaculture Research (CLAR), Abbaassa, Abou-Hammmad, Sharkia, Egypt to study the effect of different water sources on some water quality characteristics as well as on both the survival rate and growth performance of Nile tilapia larvae during 2019.

Healthy 450 thousands of Nile tilapia larvae were distributed in 9 concrete ponds, each pond, of $2.8 \times 8.1 \times 1.5 \mathrm{~m}$, filled with water at a height of $1 \mathrm{~m}$ and stocked with 50 thousands Nile tilapia larvae. The ponds divided into 3 treatments, each treatment with triplicates. The first treatment has a Ground Water source $(\mathrm{GW})$, the third treatment has agricultural drainage water source (DW) and the second treatment has mixed water (MW, 50\% ground water and 50\% agricultural drainage water).

Larvae were fed an artificial diet (48\% protein) 6 times daily (AbouZied and Ali 2015) at the rate of 35\%, 26\% and $18 \%$ from their body weight in the $1^{\text {st }}, 2^{\text {nd }}$ and $3^{\text {rd }}$ week respectively. This experiment was replicated four times, each nursing period lasted for 21 days. At the end of each period, fry number was estimated in each pond; the survival and growth rates were calculated.

\section{Water quality determination:}

In estimating the quality of inlet water as well as water within ponds at the end of each nursing period, some chemical properties of the water were analyzed including: total hardness, total Alkalinity, total ammonia $\left(\mathrm{NH}_{3}+\mathrm{NH}_{4}\right)$, nitrite $\left(\mathrm{NO}_{2}-\mathrm{N}\right)$, nitrate $\left(\mathrm{NO}_{3}-\mathrm{N}\right)$, total phosphorous (TP) (Pulatsu, et al., 2004) and ortho-phosphate.

Water total hardness was measured using EDTA titration method in the presence of Erichrome Black $T$ agent (AOAC 1990). Total alkalinity was measured applying titration method using $0.02 \mathrm{~N} \mathrm{HCl}$ in the presence of phenolphthalein indicator (AOAC 1990). Total $\mathrm{NH}_{3}, \mathrm{NO}_{2}$, $\mathrm{NO}_{3}$ were measured according to AOAC (1990) methods. Total phosphorus (TP) and orthophosphate (OP) were determined applying ascorbic acid method (AOAC 1990). Water samples were taken from the water sources at each time of ponds filling and from the ponds at the end of each rearing period. 


\section{Statistical analysis.}

Data were analyzed using SPSS program and one way analysis of variance (ANOVA)

and the new LSD test were performed to determine significant differences among means (Steel and Torrie, 1980).

\section{RESULTS and DISCUSSION}

The water quality parameters in the inlet water and the water within the ponds at the end of each of four successive larvae nursing periods, each of 21 days, are presented in Tables 1 and 2.

Table (1) Water quality parameters of different water sources used to fill Nile tilapia $O$. niloticus larvae ponds .

\begin{tabular}{|l|l|l|l|l|l|l|l|}
\hline Rarameters & $\begin{array}{l}\text { T. A. } \\
\mathbf{m g} / \mathbf{L}\end{array}$ & $\begin{array}{l}\text { T. H. } \\
\mathbf{m g} / \mathbf{L}\end{array}$ & $\begin{array}{l}\mathbf{O . P .} \\
\mathbf{m g} / \mathbf{l}\end{array}$ & $\begin{array}{l}\text { T. P. } \\
\mathbf{m g} / \mathbf{l}\end{array}$ & $\begin{array}{l}\mathbf{N H}_{3} \\
\mathbf{m g} / \mathbf{l}\end{array}$ & $\begin{array}{l}\mathbf{N o} 2 \\
\mathbf{m g} / \mathbf{l}\end{array}$ & $\begin{array}{l}\mathbf{N O}_{3} \\
\mathbf{m g} / \mathbf{l}\end{array}$ \\
\hline $\begin{array}{l}\text { Ground } \\
\text { water }\end{array}$ & $\begin{array}{l}201.7 \\
\pm 2.9\end{array}$ & $\begin{array}{l}276.7 \pm 3 \\
0.6\end{array}$ & $\begin{array}{l}0.118 \pm \\
0.003\end{array}$ & $\begin{array}{l}0.124 \pm 0 . \\
004\end{array}$ & $\begin{array}{l}0.083 \pm 0 . \\
025\end{array}$ & $\begin{array}{l}0.043 \pm 0 . \\
003\end{array}$ & $\begin{array}{l}0.15 \pm 0.0 \\
3\end{array}$ \\
\hline $\begin{array}{l}\text { Drainage } \\
\text { water }\end{array}$ & $\begin{array}{l}251.7 \pm \\
7.6\end{array}$ & $\begin{array}{l}382.7 \pm \\
33.7\end{array}$ & $\begin{array}{l}0.27 \pm 0 . \\
008\end{array}$ & $\begin{array}{l}0.326 \pm 0 . \\
014\end{array}$ & $\begin{array}{l}0.38 \pm 0.0 \\
95\end{array}$ & $\begin{array}{l}0.085 \pm 0 . \\
004\end{array}$ & $\begin{array}{l}1.307 \pm 0 . \\
061\end{array}$ \\
\hline
\end{tabular}

T.A. $=$ Total alkalinity $\left(\right.$ as $\left.\mathrm{CaCO}_{3}\right)$, T.H. $=$ Total Hardness $\left(\right.$ as $\left.\mathrm{CaCO}_{3}\right)$, O.P.= Ortho phosphate, T.P.=Total phosphorus, $\mathrm{NH}_{3}=$ unionized ammonia-N., $\mathrm{NO} 2=$ nitrite, $\mathrm{NO}_{3}=$ nitrate

The total hardness and total alkalinity values in the ground water were $276.7 \pm 30.6$ and $201.7 \pm 2.9 \mathrm{mg} \mathrm{CaCO}_{3} l^{-1}$, respectively, while in the agricultural drainage water these values were $382.7 \pm 33.7$ and $251.7 \pm$ $7.6 \mathrm{mg} \mathrm{CaCO} 3 l^{-1}$, respectively. These values are relatively higher than the acceptable values for aquaculture activity as stated in several studies for optimum fish growth, particularly for Nile tilapia fish. According to Stone and Thomforde (2004) the desirable range of total hardness is 50$150 \mathrm{mg} \mathrm{l}^{-1}$ as $\mathrm{CaCO}_{3}$. Zaki (2014) reported that the permissible range of total hardness $190-214 \mathrm{mg} / \mathrm{l}$ for Nile tilapia and a range of $208-233 \mathrm{mg} / \mathrm{l}$ for total alkalinity. Higher total hardness was measured at the same site of the present work by Saeed (2013) 310-350 mg $\mathrm{CaCO}_{3} / \mathrm{l}$, whereas similar values for total alkalinity $366.67 \mathrm{mg} \mathrm{CaCO}_{3} / 1$. Wafeek et al. (2014) investigated the effect of water quality on the reproductive performance of Nile tilapia at the same site of the present study and found that the total hardness ranged between $394-424 \mathrm{mg} / \mathrm{l}$, while total alkalinity ranged between $225-237.2 \mathrm{mg} / 1$ for agricultural drainage water. 
Table (2) Water quality parameters within Nile tilapia $O$. niloticus larvae ponds at the end of four successive rearing periods, each lasted for 21 days.

\begin{tabular}{|c|c|c|c|c|c|c|c|c|}
\hline & & $\begin{array}{l}\text { T. A. } \\
\text { mg/L }\end{array}$ & $\begin{array}{l}\text { T. H. } \\
\text { mg/L }\end{array}$ & $\begin{array}{l}\text { O. P. } \\
\mathrm{mg} / \mathrm{l}\end{array}$ & $\begin{array}{l}\text { T. P. } \\
\text { mg/l }\end{array}$ & $\begin{array}{l}\mathrm{NH}_{3} \\
\mathrm{mg} / \mathrm{l}\end{array}$ & $\begin{array}{l}\mathrm{NO}_{2} \\
\mathrm{mg} / \mathrm{l}\end{array}$ & $\begin{array}{l}\mathrm{NO}_{3} \\
\mathrm{mg} / \mathrm{l}\end{array}$ \\
\hline \multirow{3}{*}{ H1 } & G.W & $\begin{array}{c}225 \\
\pm 2.89^{\mathrm{a}}\end{array}$ & $\begin{array}{c}275 \\
\pm 14.83^{\mathrm{a}}\end{array}$ & $\begin{array}{c}0.195 \\
\pm 0.002^{\mathrm{a}}\end{array}$ & $\begin{array}{c}0.264 \\
\pm 0.007^{\mathrm{a}}\end{array}$ & $\begin{array}{c}0.342 \\
\pm 0.035^{\mathrm{a}}\end{array}$ & $\begin{array}{c}0.190 \\
\pm 0.001^{\mathrm{a}}\end{array}$ & $\begin{array}{c}0.818 \\
\pm 0.093^{\mathrm{a}}\end{array}$ \\
\hline & M.W & $\begin{array}{c}227 \\
\pm 2.67^{\mathrm{a}}\end{array}$ & $\begin{array}{c}318 \\
\pm 16.42^{\mathrm{ab}}\end{array}$ & $\begin{array}{c}0.264 \\
\pm 0.005^{\mathrm{b}}\end{array}$ & $\begin{array}{c}0.361 \\
\pm 0.008^{\mathrm{b}}\end{array}$ & $\begin{array}{c}0.478 \\
\pm 0.027^{\mathrm{ab}}\end{array}$ & $\begin{array}{c}0.205 \\
\pm 0.003^{\mathrm{b}}\end{array}$ & $\begin{array}{c}1.502 \\
\pm 0.044^{\mathrm{b}}\end{array}$ \\
\hline & D.W & $\begin{array}{c}246 \\
\pm 2.09^{\mathrm{b}}\end{array}$ & $\begin{array}{c}375 \\
\pm 19.76^{\mathrm{b}}\end{array}$ & $\begin{array}{c}0.346 \\
\pm 0.004^{\mathrm{c}}\end{array}$ & $\begin{array}{c}0.460 \\
\pm 0.008^{c}\end{array}$ & $\begin{array}{c}0.617 \\
\pm 0.055^{\mathrm{b}}\end{array}$ & $\begin{array}{c}0.232 \\
\pm 0.002^{\mathrm{c}}\end{array}$ & $\begin{array}{c}2.082 \\
\pm 0.035^{\mathrm{c}}\end{array}$ \\
\hline \multirow{3}{*}{ H2 } & G.W & $\begin{array}{c}220 \\
\pm 2.03^{\mathrm{a}}\end{array}$ & $\begin{array}{c}274 \\
\pm 13.57^{\mathrm{a}}\end{array}$ & $\begin{array}{c}0.460 \\
\pm 0.036^{\mathrm{a}}\end{array}$ & $\begin{array}{c}0.748 \\
\pm 0.043^{\mathrm{a}}\end{array}$ & $\begin{array}{c}0.725 \\
\pm 0.015^{\mathrm{a}}\end{array}$ & $\begin{array}{c}0.418 \\
\pm 0.001^{\mathrm{a}}\end{array}$ & $\begin{array}{c}1.867 \\
\pm 0.017^{\mathrm{a}}\end{array}$ \\
\hline & M.W & $\begin{array}{c}226 \\
\pm 3.18^{\mathrm{a}}\end{array}$ & $\begin{array}{c}317 \\
\pm 15.82^{\mathrm{ab}}\end{array}$ & $\begin{array}{c}0.566 \\
\pm 0.005^{\mathrm{b}}\end{array}$ & $\begin{array}{c}0.895 \\
\pm 0.008^{\mathrm{b}}\end{array}$ & $\begin{array}{c}0.883 \\
\pm 0.027^{\mathrm{b}}\end{array}$ & $\begin{array}{c}0.433 \\
\pm 0.003^{\mathrm{b}}\end{array}$ & $\begin{array}{c}2.444 \\
\pm 0.044^{\mathrm{b}}\end{array}$ \\
\hline & D.W & $\begin{array}{c}248 \\
\pm 4.06^{\mathrm{b}}\end{array}$ & $\begin{array}{c}372 \\
\pm 17.89^{\mathrm{b}}\end{array}$ & $\begin{array}{c}0.648 \\
\pm 0.004^{\mathrm{c}}\end{array}$ & $\begin{array}{c}0.949 \\
\pm 0.008^{c}\end{array}$ & $\begin{array}{c}1.022 \\
\pm 0.055^{\mathrm{c}}\end{array}$ & $\begin{array}{c}0.463 \\
\pm 0.002^{\mathrm{c}}\end{array}$ & $\begin{array}{c}3.255 \\
\pm 0.259^{c}\end{array}$ \\
\hline \multirow{3}{*}{ H3 } & G.W & $\begin{array}{c}224 \\
\pm 2.73^{\mathrm{a}}\end{array}$ & $\begin{array}{c}270 \\
\pm 11.26^{\mathrm{a}}\end{array}$ & $\begin{array}{c}0.861 \\
\pm 0.012^{\mathrm{a}}\end{array}$ & $\begin{array}{c}1.460 \\
\pm 0.002^{\mathrm{a}}\end{array}$ & $\begin{array}{c}1.195 \\
\pm 0.015^{\mathrm{a}}\end{array}$ & $\begin{array}{c}0.813 \\
\pm 0.001^{\mathrm{a}}\end{array}$ & $\begin{array}{c}3.218 \\
\pm 0.017^{\mathrm{a}}\end{array}$ \\
\hline & M.W & $\begin{array}{c}225 \\
\pm 2.65^{\mathrm{a}}\end{array}$ & $\begin{array}{c}313 \\
\pm 14.57^{\mathrm{a}}\end{array}$ & $\begin{array}{c}0.943 \\
\pm 0.005^{\mathrm{b}}\end{array}$ & $\begin{array}{c}1.563 \\
\pm 0.008^{\mathrm{b}}\end{array}$ & $\begin{array}{c}1.353 \\
\pm 0.027^{\mathrm{b}}\end{array}$ & $\begin{array}{c}0.828 \\
\pm 0.003^{\mathrm{b}}\end{array}$ & $\begin{array}{c}3.795 \\
\pm 0.044^{\mathrm{b}}\end{array}$ \\
\hline & D.W & $\begin{array}{c}247 \\
\pm 2.03^{\mathrm{b}}\end{array}$ & $\begin{array}{c}370 \\
\pm 17.56^{\mathrm{b}}\end{array}$ & $\begin{array}{c}1.025 \\
\pm 0.004^{\mathrm{c}}\end{array}$ & $\begin{array}{c}1.662 \\
\pm 0.008^{c}\end{array}$ & $\begin{array}{c}1.492 \\
\pm 0.055^{\mathrm{c}}\end{array}$ & $\begin{array}{c}0.855 \\
\pm 0.002^{c}\end{array}$ & $\begin{array}{c}4.375 \\
\pm 0.035^{\mathrm{c}}\end{array}$ \\
\hline \multirow{3}{*}{ H4 } & G.W & $\begin{array}{c}229 \\
\pm 2.65^{\mathrm{a}}\end{array}$ & $\begin{array}{c}282 \\
\pm 10.71^{\mathrm{a}}\end{array}$ & $\begin{array}{c}0.504 \\
\pm 0.013^{\mathrm{a}}\end{array}$ & $\begin{array}{c}0.839 \\
\pm 0.022^{\mathrm{a}}\end{array}$ & $\begin{array}{c}0.741 \\
\pm 0.009^{\mathrm{a}}\end{array}$ & $\begin{array}{c}0.400 \\
\pm 0.085^{\mathrm{a}}\end{array}$ & $\begin{array}{c}1.821 \\
\pm 0.119^{\mathrm{a}}\end{array}$ \\
\hline & M.W & $\begin{array}{c}229 \\
\pm 2.33^{\mathrm{a}}\end{array}$ & $\begin{array}{c}338 \\
\pm 11.61^{\mathrm{b}}\end{array}$ & $\begin{array}{c}0.552 \\
\pm 0.024^{\mathrm{a}}\end{array}$ & $\begin{array}{c}0.967 \\
\pm 0.011^{\mathrm{a}}\end{array}$ & $\begin{array}{c}0.898 \\
\pm 0.033^{\mathrm{a}}\end{array}$ & $\begin{array}{c}0.477 \\
\pm 0.028^{\mathrm{a}}\end{array}$ & $\begin{array}{c}2.551 \\
\pm 0.052^{\mathrm{b}}\end{array}$ \\
\hline & D.W & $\begin{array}{c}251 \\
\pm 3.21^{\mathrm{b}}\end{array}$ & $\begin{array}{c}363 \\
\pm 10.41^{\mathrm{b}}\end{array}$ & $\begin{array}{c}0.664 \\
\pm 0.008^{\mathrm{b}}\end{array}$ & $\begin{array}{c}1.228 \\
\pm 0.097^{\mathrm{b}}\end{array}$ & $\begin{array}{c}1.127 \\
\pm 0.107^{\mathrm{b}}\end{array}$ & $\begin{array}{c}0.604 \\
\pm 0.091^{\mathrm{b}}\end{array}$ & $\begin{array}{c}3.146 \\
\pm 0.055^{\mathrm{c}}\end{array}$ \\
\hline
\end{tabular}

Mean having different small letters are significantly different $(\mathrm{p} \leq 0.05)$.

Calcium and magnesium are essential to fish for metabolic reactions such as bone and scale formation (Bhatnagar and Devi, 2013). Thus, Wurts and Durborow (1992) recommended a range for free calcium in culture waters of 25 to $100 \mathrm{mg} \mathrm{L}^{-1}$ (which equal to 63 to $250 \mathrm{mg} \mathrm{l}^{-1}$ $\mathrm{CaCO}_{3}$ hardness).

Wurst and Duborrow (1992) and Boyd (1998) reported that total alkalinity higher than $20 \mathrm{mg} / \mathrm{l}$ is necessitate for good productivity in fish 
ponds, and the desirable total alkalinity range is between 75 and 200 $\mathrm{mg} / \mathrm{l}$. Boyd (1998) reported that increasing total alkalinity up to least 150 $\mathrm{mg} / \mathrm{l}$ results in an increase of pond water fertility.

In the present study, the total hardness: total alkalinity ratio (TH : Talk ratio) in the ground water was found to be 1.4 , while it was 1.5 in the agricultural drainage water (Table 1). Within the ponds during the study the TH :Talk ratio was found to range between 1.2-1.25; 1.39-1.48 and 1.12- 1.5 for ground water, mixed water and agricultural drainage water, respectively (Table 2). Cavalcante et al. (2012) demonstrated improvement in Nile tilapia growth when hardness : alkalinity ratio is maintained equal or superior to 1.0.

During the present study, the hardness values ranged between $270 \pm 11.3$ and $372 \pm 17.89 \mathrm{mg} \mathrm{Ca}_{3} \mathrm{CO}_{3} / \mathrm{l}$, which is higher than the total alkalinity values that ranged between $220 \pm 2.03$ and $251 \pm 3.21$ $\mathrm{mgCa}_{3} \mathrm{CO}_{3} / \mathrm{l}$ in ponds. This is in consistence with Boyd and Tucker (1998) who reported that, generally, total hardness is consistently greater in concentration than total alkalinity as a common phenomenon in aquaculture ponds. Total hardness concentrations above $200 \mathrm{mg} / \mathrm{l}$ are acceptable (Boyd and Tucker, 1998). Heath (1987) and Meade (1989) noted positive effects on fish health in waters with hardness in excess of $\sim 400 \mathrm{mg} / \mathrm{l}$ as $\mathrm{CaCO}_{3}$. In contrast, low alkalinities generally contributed to fish stress only when elevated concentrations of $\mathrm{CO}_{2}$ (Viadero 2005).

In fact the high levels of hardness and alkalinity in the utilized water sources can be considered as a merit, since they are reported to reduce the toxicity of some heavy metals Pascoe et al. (1986) and Linbo et al. (2009).

Ammonia is the principal nitrogenous waste product excreted by fishes and is usually oxidized to nitrite and nitrate. Ammonia is excreted by gills beside urea and amines (Wood, 1993). While, creatine, creatinine, uric acid, trimethylamine (TMA), and trimethylamine oxide (TMAO) are being excreted through the kidneys (De Croux et al., 2004; Kajimura et al., 2004).

The total ammonia concentration in the inlet water was $0.083 \pm 0.025$ $\mathrm{mg} / \mathrm{l}$ in ground water and $0.38 \pm 0.093 \mathrm{mg} / \mathrm{l}$ in agricultural drainage water. During the study the total ammonia concentrations significantly differed among treatments with the lowest values recorded at the ground water treatments and the highest values recorded at the agricultural drainage water. This is inconsistence with Randall and Tsui (2002) who mentioned agricultural run-off and organic wastes deposition as the main 
factors for high ammonia level in aquatic environment. John and Semra (2001) reported that at $0.91 \mathrm{mg} / \mathrm{l}$ unionized ammonia-N there was no effect on growth or feed conversion ratio of channel catfish and blue tilapia. However, Saber et al. (2004) showed that the lowest-observable effect concentration on the growth performance of Nile tilapia is 0.144 $\mathrm{mg} / \mathrm{l}$ unionized ammonia-N. On contrary, El-Sherif et al. (2008) reported that the $48 \mathrm{hr}-\mathrm{LC}_{50}$ for tilapia fingerlings was $7.1 \mathrm{mg} / \mathrm{l} \mathrm{NH}-\mathrm{N}$. Daud $\boldsymbol{e t}$ al. (1988) also reported $6.6 \mathrm{mg} \mathrm{NH}-\mathrm{N} / \mathrm{l} 48-\mathrm{h} \mathrm{LC}_{50}$ in hybrid tilapia species (O. mossambicus $\times$ O. niloticus). Barry and Robert (1979) and

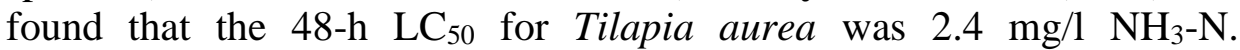
Interestingly, chronic exposure of rainbow trout (Oncorhynchus mykiss) to very low non-ionized ammonia levels $(0.01 \mathrm{mg} / \mathrm{l}$ at $\mathrm{pH} 7.6$ and 0.002 $\mathrm{mg} / \mathrm{l}$ at $\mathrm{pH}$ 6.3) for 70 days was reported to stimulate growth and protein production without increasing food consumption (Wood 2004). Nevertheless, long-term exposure to sub-acute unionized ammonia concentrations can result in decreased productivity (Soderberg and Meade. 1992) and changes in gill structure which may result in death from oxygen deficiency. Evans \& Pasnik (2006) reported that the lethal concentration at $96 \mathrm{hr}$ of ammonia is $0.96 \mathrm{mg} \mathrm{NH}_{3} / \mathrm{l}$. However, for tilapia cultures (Suresh 2003) showed that total ammonia nitrogen can be fatal above $1 \mathrm{mg} / \mathrm{l}$.

The relatively high ammonia concentrations in the present study may be explained by that the young fish produce more ammonia and urea than larger fish. This is confirmed by Dosdat et al. (1996) who reported that juveniles of brown trout, turbot and sea bass of $10 \mathrm{~g}$ produce proportionally more ammonia and urea than fishes that of $100 \mathrm{~g}$ in weight.

In the present study we did not notice negative influence of ammonia on tilapia fingerlings in term of survival rate. This can be attributed to the high levels of water alkalinity, where nitrifying bacteria can utilize inorganic carbon, mainly from alkalinity, in nitrification process. Also the hardness cations may reduce the toxic effect of ammonia by altering the osmoregulatory systems of fish and decreasing membrane permeability (Burton \& Prosser 2001; Chen et al., 2012).

In the inlet water the nitrite concentration was determined at $0.043 \pm 0.003 \mathrm{mg}-\mathrm{NO}_{2}-\mathrm{N} / \mathrm{l}$ in ground water, while it was at $0.085 \pm 0.004$ $\mathrm{mg}-\mathrm{NO}_{2}-\mathrm{N} / \mathrm{l}$ in the agricultural drainage water (table 1 ).

During the present study the nitrite values showed significant differences among treatments with the highest values at the agricultural 
drainage water and the lowest values in the ground water treatment (table 2).

Nitrite is toxic to many fish species however its toxic limit is dependent on the size of the fish (Palachek and Tomasso 1984a). Atwood et al., (2001) reported that Nile tilapias Oreochromis niloticus fingerlings $(4.4 \pm 1.50 \mathrm{~g})$ are more tolerant than larger fishes $(90.7 \pm$ $16.43 \mathrm{~g}$ ) for $\mathrm{NO}_{2}$. They showed that the 96-h median lethal concentration of nitrite- $\mathrm{N}$ to small fish is $81 \mathrm{mg} \mathrm{l}^{-1}\left(35-127 \mathrm{mg} \mathrm{l}^{-1}\right)$ compared to $8 \mathrm{mgl}^{-1}$ (4-11 $\left.\mathrm{mg} \mathrm{l}^{-1}\right)$ for large fish. For blue tilapia Oreochromis aureus $(3.4 \mathrm{~g})$, the $96-\mathrm{h} \mathrm{LC} \mathrm{LC}_{50}$ of nitrite-N is reported at $16.2 \mathrm{mgl}^{-1}$ in $23^{\circ} \mathrm{C}$ freshwater according to Palachek and Tomasso (1984b). However, OATA (2008) recommended that it should not exceed $0.2 \mathrm{mgl}^{-1}$ in freshwater aquaculture. Santhosh and Singh (2007) recommended nitrite concentration in water should not exceed $0.5 \mathrm{mg} \mathrm{l}^{-1}$.

Nitrite resulting in transferring fish haemoglobin to methemoglobin through oxidizing $\mathrm{Fe}^{2+}$ to $\mathrm{Fe}^{3+}$ (Palachek and Tomasso, 1984b), which has low oxygen-carrying capacity. However, Yildiz et al. (2006) reported that the levels of methemoglobin in Nile tilapia are not related to environmental and plasmatic nitrite concentrations. Furthermore, the percentages of methemoglobin declined in fish exposed to high levels of $\mathrm{NO}_{2}-\mathrm{N}$ concentrations $\left(0.5-1 \mathrm{mg} \mathrm{NO} \mathrm{NO}_{2}-\mathrm{N} \mathrm{l}^{-1}\right)$ after $48 \mathrm{~h}$ and no mortality among Nile tilapia fish was recorded (Yildiz et al., 2006).

The nitrate concentration in the inlet water in the ground water was $0.15 \pm 0.03 \mathrm{mg} \mathrm{NO}-\mathrm{Nl}^{-1}$, while it was $1.307 \pm 0.061 \mathrm{mg} \mathrm{NO}-\mathrm{Nl}^{-1}$ in the agricultural drainage water. As, there were significant differences among treatments in nitrate during the experiment with the highest values recorded in agricultural drainage water treatment and the lowest values were determined in the ground water treatment. This difference can be attributed water replacement during the rearing period as well as to introduce artificial feed. This explanation is confirmed by Svobodová $\boldsymbol{e t}$ al. (1993) who reported that the main sources of nitrate pollution of surface waters are the use of nitrogenous fertilizers and manures, which explain why nitrate was higher in the agricultural drainage water. However, the levels of nitrate measured in the present study are still within the safe limit, so the nitrate had not any negative influence on the Nile tilapia fry survival or growth performance. Monsees et al. (2017) reported that the nitrate values below $500 \mathrm{mg} / \mathrm{l}$ ensure the optimum growth and health to Nile tilapia. 
The ortho-phosphate in the ground water was measured at $0.118 \pm$ $0.003 \mathrm{mg} \mathrm{Pl}^{-1}$, while it was $0.27 \pm 0.008 \mathrm{mg} \mathrm{Pl}^{-1}$ at the filling times. Similarly, total phosphorus in the inlet water of ground water treatment was determined as $0.124 \pm 0.004 \mathrm{mg} \mathrm{Pl}^{-1}$, while in agricultural drainage water as $0.326 \pm 0.014 \mathrm{mg} \mathrm{Pl}^{-1}$. During the experiment, both reactive phosphate and total water phosphorous have same manner with the significant highest values in the agricultural drainage water and the significant lowest values in the ground water treatment.

Phosphorus is an important mineral in nucleic acids and cellular membranes, the main representative of the structural components of the skeletal tissues, and it is directly involved in energy processes (NRC, 1993). However, the fish retention efficiency of $P$ in diet is low. Lazzari and Baldisserotto (2008) reported that phosphorus excretion, usually 6986\% of dietary P. Though, Sarka et al. (2002) reported that Nile tilapia can utilize the phosphorus in inorganic fertilizers (Triple super phosphate and $16 \mathrm{~N}: 20 \mathrm{P}_{2} \mathrm{O}_{5}$ grade inorganic fertilizer) supplemented in diets as phosphorus sources equivalently to DCP (Di-calcium phosphate) in terms of growth performance, feed utilization efficiency and final body composition. Moreover, Fish can absorb phosphorus at low rate from water through gills (for review Hepher 1984) but not sufficiently to satisfy their phosphorus requirements, therefore, dietary supplementation is necessary.

Stone and Thomforde (2004) reported that the phosphate level of $0.06 \mathrm{mg} \mathrm{l}^{-1}$ is desirable for fish culture. Bhatnagar et al. (2004) suggested 0.05-0.07 ppm of phosphate is optimum and productive fish ponds; $1.0 \mathrm{ppm}$ is good for plankton / shrimp production. In fish, a certain amount of non-fecal $\mathrm{P}$ excretion is unavoidable and occurs even at zero intake of P. Consequently, the non-fecal $\mathrm{P}$ excretion has been found to be unaffected by $\mathrm{P}$ intake up to the level required by the experimental animal (Rodehutscord et al., 1994).

Table 3 shows the number of larvae harvested after the nursing periods (each of 21 days). From the table we can note that there are significant differences in the number of larvae that were harvested from ponds of mixed water treatment that were significantly higher (39375) than those harvested from groundwater ponds (34125), while the significantly lowest number of larvae harvested was in the agricultural drainage water treatment (30250). These results can be explained by that the mixture water containing the most appropriate levels of alkalinity, total Hardness, ammonia, nitrite and lower levels of pollutants compared to groundwater ponds as well as agricultural drainage water ponds. On 
the other hand, agricultural drainage water may contain many pollutants that have not been estimated, such as heavy metals and pesticides, as a result of agricultural activities. The number of larvae harvested from draining water ponds was acceptable due to high content of alkalinity, total hardness which increased divalent cation concentrations that may reduce the toxicity of $\mathrm{NH}_{3}-\mathrm{N}$ by altering the osmoregulatory systems of fish and decreasing membrane permeability (Potts and Fleming 1970).

Table 3 Mean \pm SE of larvae number/Pond of Nile tilapia $O$. niloticus at the end of four successive nursing periods, each lasted for 21 days.

\begin{tabular}{|l|c|c|c|}
\hline Items & Ground Water & Mixed Water & $\begin{array}{c}\text { Drainage } \\
\text { Water }\end{array}$ \\
\hline Harvest 1 & $36166 \pm 726^{\mathrm{b}}$ & $41166 \pm 881^{\mathrm{a}}$ & $31000 \pm 577^{\mathrm{c}}$ \\
\hline Harvest 2 & $33500 \pm 288^{\mathrm{b}}$ & $39833 \pm 166^{\mathrm{a}}$ & $30166 \pm 600^{\mathrm{c}}$ \\
\hline Harvest 3 & $33833 \pm 440^{\mathrm{b}}$ & $39333 \pm 166^{\mathrm{a}}$ & $30166 \pm 600^{\mathrm{c}}$ \\
\hline Harvest 4 & $33000 \pm 577^{\mathrm{b}}$ & $37166 \pm 440^{\mathrm{a}}$ & $29666 \pm 881^{\mathrm{c}}$ \\
\hline Average & $34125 \pm 288^{\mathrm{b}}$ & $39375 \pm 260^{\mathrm{a}}$ & $30250 \pm 625^{\mathrm{c}}$ \\
\hline
\end{tabular}

Average in the same row having different superscripts are differ significantly $(\mathrm{P} \leq 0.05)$.

Table 4 shows the survival rate of larvae harvested after the nursing period ( 21 days). The results take the same trend of number of harvested larvae. The significantly highest survival rate obtained in ponds of mixed water treatment $(78.75 \%)$ followed by that in groundwater ponds $(68.25 \%)$ and finally ponds agricultural drainage water $(60.50 \%)$.

Table 5 shows the growth rates of the larvae harvested after the nursing period (21 days). The results show that there are significant differences in the growth rates. The significantly highest growth rates were obtained in mixed water ponds treatment with average weight (342.5 mg) followed by the larvae nursed in the agricultural drainage ponds $(320.5 \mathrm{mg})$. However, the larvae reared in groundwater ponds treatments had the significantly lowest weight $(307 \mathrm{mg})$. These differences may be due to the mixture water containing the most suitable levels of alkalinity, Hardness, ammonia and nitrite, which leads to an increase in the rate of growth and reduction of ammonia toxicity and this corresponds to the results obtained by Stone and Thomforde (2004). Although increasing ammonia in agricultural drainage ponds, but the presence of suitable levels of alkalinity and total hardness may result in 
less ammonia effect which increases the growth rate as reported by (Burton and Prosser 2001; Chen et al., 2012).

Table 4 : Mean \pm SE of survival rate in Nile tilapia $O$. niloticus larvae ponds at the end of four successive nursing periods, each lasted for 21 days.

\begin{tabular}{|l|l|l|l|}
\hline Items & Ground Water & Mixed Water & $\begin{array}{l}\text { Drainage } \\
\text { Water }\end{array}$ \\
\hline Harvest 1 & $72.33 \pm 1.452^{\mathrm{b}}$ & $83.33 \pm 1.763^{\mathrm{a}}$ & $62.00 \pm 1.154^{\mathrm{c}}$ \\
\hline Harvest 2 & $67.00 \pm 0.57^{\mathrm{b}}$ & $79.67 \pm 0.333^{\mathrm{a}}$ & $60.33 \pm 1.333^{\mathrm{c}}$ \\
\hline Harvest 3 & $67.67 \pm 0.881^{\mathrm{b}}$ & $78.67 \pm 0.333^{\mathrm{a}}$ & $60.33 \pm 1.201^{\mathrm{c}}$ \\
\hline Harvest 4 & $66.00 \pm 1.154^{\mathrm{b}}$ & $74.33 \pm 0.881^{\mathrm{a}}$ & $59.33 \pm 1.763^{\mathrm{c}}$ \\
\hline Average & $68.25 \pm 0.333^{\mathrm{b}}$ & $78.75 \pm 0.577^{\mathrm{a}}$ & $60.50 \pm 1.333^{\mathrm{c}}$ \\
\hline
\end{tabular}

Average in the same row having different superscripts are differ significantly $(\mathrm{P} \leq 0.05)$.

Table 5 Mean \pm SE of larvae growth performance $(\mathrm{mg})$ in Nile tilapia $O$. niloticus larvae ponds at the end of four successive nursing periods, each lasted for 21 days.

\begin{tabular}{|l|l|l|l|}
\hline Items & Ground Water & Mixed Water & $\begin{array}{l}\text { Drainage } \\
\text { Water }\end{array}$ \\
\hline Harvest 1 & $308.33 \pm 1.666^{\mathrm{c}}$ & $345.00 \pm 2.886^{\mathrm{a}}$ & $320.00 \pm 2.886^{\mathrm{b}}$ \\
\hline Harvest 2 & $304.33 \pm 2.333^{\mathrm{c}}$ & $342.33 \pm 1.452^{\mathrm{a}}$ & $320.00 \pm 2.886^{\mathrm{b}}$ \\
\hline Harvest 3 & $310.00 \pm 2.886^{\mathrm{c}}$ & $341.67 \pm 1.666^{\mathrm{a}}$ & $311,67 \pm 4.409^{\mathrm{b}}$ \\
\hline Harvest 4 & $305.33 \pm 2.905^{\mathrm{c}}$ & $341.00 \pm 2.081^{\mathrm{a}}$ & $321.67 \pm 4.409^{\mathrm{b}}$ \\
\hline Average & $307.00 \pm 0.577^{\mathrm{c}}$ & $342.50 \pm 2.185^{\mathrm{a}}$ & $320.56 \pm 1.527^{\mathrm{b}}$ \\
\hline
\end{tabular}

Average in the same row having different superscripts are differ significantly $(\mathrm{P} \leq 0.05)$.

From tables (3,4 and 5), the mixed water treatment resulted significantly higher survival rate as well as growth performance. This can be partially attributed to that total hardness: total alkalinity ratio of mixed water remained higher than that of ground water, however, it was lower than that of the agricultural drainage water. Cavalcante et al. (2012) 
demonstrated improvement in Nile tilapia growth when hardness : alkalinity ratio is maintained equal or superior to $1.0: 1.0$.

On the other hand the total alkalinity of mixed water treatment was above $200 \mathrm{mg} \mathrm{CaCO} 3 \mathrm{mg} / \mathrm{l}$ and lower, by more than $20 \mathrm{mg} \mathrm{CaCO} \mathrm{mg}_{3} \mathrm{~m}$, than that of the agricultural drainage water treatment. Boeuf and Payan, (2001) showed that at high alkalinity, fish consume higher energy in osmoregulation, since the accumulation of $\mathrm{HCO}_{3}{ }^{-}$in water may have reduced the excretion of these ions and $\mathrm{Cl}^{-}$absorption.

\section{CONCLUSIONS}

According to the results of the present study, it is clear that the ground water is suitable for aquaculture activity. Moreover, higher water quality and fish growth performance can be achieved by mixing the ground water with the agricultural drainage water.

The high alkalinity and hardness in the different studied water sources make an additional defense for the toxicity of ammonia as well as of heavy metal that may exist periodically in the agricultural drainage water as a result of applying agricultural chemical fertilizers and organic fertilizers.

Mixing the ground water with agricultural drainage water results in higher water quality than that of the ground water as it dilutes the pesticides that may exist in the agricultural drainage water and subsequently yields higher growth performance in fish.

The present study also showed that the effluent of Nile tilapia larvae ponds is rich in $\mathrm{N}$ and $\mathrm{P}$ wastes that can result in eutrophication in the receiving water bodies. These pollutant wastes can be efficiently utilized in duckweed production as recommended by (Ali et $\boldsymbol{a l}$. , ) as it in its turn can maintain water quality within larvae tilapia for long period without replacement.

\section{REFERENCES}

Abou Zied, R.M. and Ali, A.A.A., 2015. Effect of feeding rate and frequency on growth performance, sex conversion ratio and profitability of Nile tilapia (Oreochromis niloticus) fry in hapa at commercial hatcheries. Egyptian J. Nutrition and Feeds 18 (2) Special Issue: 451-459.

Ali A.A.A., Moustafa Y. T.A., Ahmed S. M.and Gomha S. A.A., 2020. Duckweed as a biological filter in tilapia fish hatcheries and its impact on tilapia reproduction. Abbassa int. J. Aqua., 13(1): 117 -134.

AOAC, 1990. Official Methods of Analysis of the Association of Official, Analytical Chemists, 15th ed. Association of Official Analytical Chemists, Arlington, VA. 
Atwood H. L., Fontenot Q. C., Tomasso J. R., Isely J. J., 2001. Toxicity of nitrite to Nile tilapia: Effect of fish size and environmental chloride. N. Am. J. Aquacult. 63(1): 49-51.

Barker, D., Allan, G. L., Rowland, S. J., Kennedy, J. D. and Pickles, J. M. 2009. A Guide to Acceptable Procedures and Practices for Aquaculture and Fisheries Research. Third Edition. Primary Industries (Fisheries) ACEC. Nelson Bay, Australia.

Barry, D. R. and Robert R. S., 1979. Acclimation to ammonia by Tilapia aurea. American Fisheries Society 108:383-388.

Bhatnagar A., Devi P., 2013. Water quality guidelines for the management of pond fish culture. International Journal of Environmental Sciences 3 (6):1980-2009.

Bhatnagar A., Jana S.N., Garg S.K., Patra B.C., Singh G. and Barman U.K., 2004. Water quality management in aquaculture, In: Course Manual of summerschool on development of sustainable aquaculture technology in fresh and saline waters, CCS Haryana Agricultural, Hisar (India), pp 203210.

Boeuf P., and Payan P., 2001. How should salinity influence fish growth? Comparative Biochemistry and Physiology, Part C, 130, 411-423.

Boyd E.C., 1998. Water quality for pond aquaculture. Research and development Series No. 43. International Center for Aquaculture and Aquatic Environments, Alabama Agricultural Experiment Station, Auburn University, James E. Marion, Director Auburn, Alabama.

Boyd C.E., and Tucker C.S., 1998. Pond Aquaculture Water Quality Management. Kluwer Academic Publishers, Boston, MA. pp. 541- 575.

Burton S. A. Q., and Prosser J. I., 2001. Autotrophic ammonia oxidation at low $\mathrm{pH}$ through urea hydrolysis. Applied and Environmental Microbiology, 67, 2952-2957.

Cavalcante D. H., Silva S. R., Pinheiro P. D., Akao M. M. F., and Sá M. V. C., 2012. Single or paired increase of total alkalinity and hardness of water for cultivation of Nile tilapia juveniles. Oreochromis Niloticus. Acta Scientiarum Technology, 32(2), 177-183. https://doi. org/10.4025/actascitechnol.v34i2.12003

Chapman G, Dunlop S., 1981. Detoxication of zinc and cadmium by the freshwater protozoan Tetrahyrnena pyriformis 1. The effect of water hardness. Environ Res 26:81-86.

Chen Y., Li S., Fang F., Guo J., Zhang Q. and Gao X., 2012. Effect of inorganic carbon on the completely autotrophic nitrogen removal over nitrite (CANON) process in a sequencing batch biofilm reactor. Environmental Technology, 33(22), 2611-2617. 
Daud S. K., Hasbollah D., and Law A. T., 1988. Effects of unionized ammonia on red tilapia (Oreochromis mossambicus $\times$ O. niloticus hybrid ) fry, p. 411 - 413. In R.S.V. Pullin, T. Bhukaswan, K. Tonguihai and J. L. Maclean (eds.) The second International Symposium on Tilapia in Aquaculture.

De Croux P., Julieta M., and Loteste A., 2004. Lethal effects of elevated $\mathrm{pH}$ and ammonia on juveniles of neotropical fish Colosoma macropomum (Pisces, Caracidae). J Environ. Biol. Jan, 25 (1): 7-10.

Dosdat A., Servais F., Metailler R., Huelvan C., and Desbruyeres E., 1996. Comparison of nitrogenous losses in five teleost fish species. Aquaculture, Amsterdam, 141:107-127.

El-Sherif, M.S. and El-Feky, A. M., 2008. Effect of ammonia on Nile tilapia (O. niloticus) performance and some hematological measures. $8^{\text {th }}$ International Symposium on Tilapia in Aquaculture 2008: p 513-530.

Evans J. J., and Pasnik, D. J., 2006. Un-ionized ammonia exposure in Nile tilapia: toxicity, stress response, and susceptibility to Streptococcus agalactiae. North American Journal of Aquaculture, 68, 23-33. https:// doi.org/10.1577/A05-032.1

Fleischman A.J., Yacowitz H., Hayton T., and Bierenbaum M.L., 1968. Effect of calcium and vitamin D 3 upon the faecal excretion of some metals in the mature male rat fed a high fat cholesterol diet. J Nutri 95:19-22.

GAFRD (General Authority for Fishery Resources Development). 2017. Year-Book of fishery statistics in Egypt (2008-2017), Cairo.

Heath A., 1987. Water Pollution and Fish Physiology, CRC Press, Boca Raton, Florida.

Helfrich L. A., and Libey G., 2015. "Fish Farming in Recirculating Aquaculture Systems (RAS)." Department of Fisheries and Wildlife Sciences Virginia Tech. Accessed Jan. 21, 2015.

Hepher B. and Sandbank S., 1984. The effects of phosphorus supplementation to common carp diets on fish growth. Aquaculture., 36: 323-332.

John , A. H. and K. Semra. 2001. Effects of dial un-ionized ammonia fluctuation on juvenile hybrid striped bass, channel catfish, and blue tilapia. Aquaculture 195, 163-181.

Kajimura M., Croke S.J., Glover C., and Wood C.M., 2004. Dogmas and controversies in the handling of nitrogenous wastes: the effect of feeding and fasting on the excretion of ammonia, urea and other nitrogenous waste products in rainbow trout. Journal of Experimental Biology, 207:1993-2002.

Khan W., Vahab A.,Masood A., and Hasan N.,2017. Water quality requirements and management strategies for fish farming (a case study of ponds around Gurgaon canal Nuh Palwal. International J. of trend in scientific Research and Development (IJTSRD), 2 (1):388-393. 
Lazzari R. and Baldisserotto B., 2008. Nitrogen and phosphorus in fish farming. B. Inst. Pesca, São Paulo, 34(4): 591 - 600.

Lewis W.M., and Morris D.P., 1986. Toxicity of nitrite to fish: A review. Trans. Amer. Fish. Soc., 115, No. 2, 183-195.

Linbo T. L., Baldwin D. H., Mcintyre J. K., and Scholz N. L., 2009. Effect of water hardness ,alkalinity and dissolved organic carbon on the toxicicty of copper to the Lateral line of developing fish. Environmental Toxicology and Chemistry, Vol. 28, No. 7, pp. 1455-1461.

Martins G.B., da-Rosa C. E., Tarouco F. d-M, Robald R. B., 2019.Growth, water quality and oxidative stress of Nile tilapia Oreochromis niloticus (L.) in biofloc technology system at different $\mathrm{pH}$. Aquaculture Research. 50:1030-1039.

Meade, J. 1989. Aquaculture Management, Van Nostrand Reinhold, New York, NY.

Mmochi A. J., Dubi A. M., Mamboya F. A., and Mwandya A. W., 2002. Effects of Fish Culture on Water Quality of an Integrated Mariculture Pond System. Western Indian Ocean J. Mar. Sci., 1 (1): 53-63.

Monsees H., Klatt L., Kloas W., and Wuertz S., 2017. Chronic exposure to nitrate significantly reduces growth and affects the health status of juvenile Nile tilapia (Oreochromis niloticus L.) in recirculating aquaculture systems. Aquaculture Research, 48, 3482-3492.

NRC. 1993. National Research Council. Nutrients requirements of fish. National Academy Press. 114p.

OATA (Ornamental Aquatic Trade Association), 2008. Water Quality Criteriaornamental fish. Company Limited by Guarantee and Registered in England No 2738119 Registered Office Wessex House, 40 Station Road, Westbury, Wiltshire, BA13 3JN, UK, info@ornamentalfish.org www.ornamentalfish.org. Version 2.0 March 2008

Palachek R. M., and Tomasso J. R., 1984a. Nitrite toxicity to fathead minnows: effect of fish weight. Bulletin of Environmental Contamination and Toxicology 32:238-242.

Palachek R. M., and Tomasso J. R., 1984b. Toxicity of nitrite to channel catfish (Ictalurus punctatus), tilapia (Tilapia aurea), and largemouth bass (Micropterus salmoides): evidence for a nitrite-exclusion mechanism. Canadian Journal of Fisheries and Aquatic Sciences 41:1739-1744.

Pascoe D., Evans S. A., and Woodworth J., 1986. Heavy metal toxicity to fish and the influence of water hardness . Arch. Environ. Contam. Toxicol. 15:481-487.

Piper R. G., McElwain I. B., Orme L. E., McCraren J. P., Flower L. G., and Leonard J. R., 1982. Fish hatchery management. U. S. Fish and Wildlife Service, Washington, D. C. 
Potts W. and Fleming W., 1970. The effects of pro-lactin and divalent ions on the permeability to water of fundulus kansae. Journal of Experimental Biology, 53: 317 - 327 .

Raju P.A.R. K. , Reddy, M.S.R., Raghuram, P. , Suri Babu, G., Rambabu T. and Jeevan Kumar J., 2014. Alkalinity and Hardness Variation in Ground Waters of East Godavari District due to Aquaculture. International Journal of Fisheries and Aquatic Studies 2014; 1(6): 121-127.

Randall D.J., and Tsui T.K.N., 2002. Ammonia toxicity in fish. Marine Pollution Bulletin ; 45 (1-2):17-23.

Rodehutscord M., Mandel S., and Pfeffer E., 1994. Reduced protein content and use of wheat gluten in diets for rainbow trout: effects on water loading $\mathrm{N}$ and P. Journal Applied Ichthyology, 10:271-273.

Saber , El-Shafai A., Fatma A. E., Fayza A. N., van der Steen N. P.and Huub J. G., 2004. Chronic ammonia toxicity to duckweed-fed tilapia $(O$. niloticus). Aquaculture 232: 117-127.

Saeed S. M., 2013. Assessment of inorganic pollutants in water and sediments in Abbassa and Maruit fish farm, Egypt. Abbassa Int. J. Aqua., 6 (1): 1939.Aquaculture 232, 117-127.

Santhosh B. and Singh N.P., 2007. Guidelines for water quality management for fish culture in Tripura, ICAR Research Complex for NEH Region, Tripura Center, Publication no.29

Sarka M.R.U., Yakupitiyage A., Lin C.K. and Little D.C., 2002. Alternative phosphorus sources for formulated fish feed. Bangladesh]. Fish. Res., 6(2): 149-158

Soderberg R. and Meade J., 1992. Effects of Sodium and Calcium on Acute Toxicity of Un-ionized Ammonia to Atlantic Salmon and Lake Trout, Journal of Applied Aquaculture, 1: 83 - 92.

Steel R.G.D., and Torrie J.H., 1980. Principles and Procedures of Statistics: A Biometrical Approach. McGraw-Hill, New York, NY.

Stone N. M. and Thomforde H. K., 2004. Understanding your fish pond water analysis report. Cooperative Extension Program, University of Arkansas at Pine Bluff Aquaculture / Fisheries.

Suresh V., 2003. Tilapias. In Aquculture:Farming aquatic animals and plants (ed. By Lucas, J.S. and Southgate, P), pp 321-345. Blackwell Publishing Ltd, Oxford, UK

Svobodová Z., Lloyd R., Machová J., and Vykusová B.,1993. Water quality and fish health. EIFAC Technical Paper. No. 54. 59p. Rome, FAO, Fisheries Department, 00100 Rome, Italy,ISBN 92-5-103437-0

Swann, L. 2010. Water Quality Water Sources Used in Aquaculture. Aquaculture extension, Sea Grant, IL-IN-SG-Fs-93-1. Fact Sheet AS-486. 
Viadero R. C., 2005. Factors affecting fish growth and production. in Water Encyclopedia, Volume 3: Surface \& Agricultural Water, Jay H. Lehr \& Jack Keeley, Eds., John Wiley \& Sons Publishing, New York, 129 - 133.

Wafeek M., Abd-Elrhman A.A., and Ahmed M.H., 2014. Water sources affecting on water quality, reproductive performance and some physiological parameters of Nile tilapia (Oreochromis niloticus). Egy.J.Aqua.; 4(2):27-40.

WHO (World Health Organization) 2003. Global journal of pure and Applied Science Vol. 4 No. 2.

Wood C.M., 2004. Dogmas and controversies in the handling of nitrogenous wastes: is exogenous ammonia a growth stimulant in fish? Journal of Experimental Biology, 207:2043-2054.

Wood, C.M., 1993. Ammonia and urea metabolism and excretion. In: EVANS, D.H. (Ed.), The physiology of fishes, $1^{\text {st }}$, ed. CRC Press, Boca Raton, 379425.

Wurst W. A., and Durborow R.M., 1992. Interactions of pH, carbon dioxide, alkalinity and hardness in fish ponds. SRAC publication No. 464.

Wyk P.V.and Scarpa J.1999. Chapter 8 - Water Quality Requirements and Management. https://www.researchgate.net/publication/284696070

Yildiz H. Y., Ko“ksal G., Borazan G. and Benli C.K., 2006. Nitrite-induced methemoglobinemia in Nile tilapia, Oreochromis niloticus. J. Appl. Ichthyol. 22 : 427-429.

Zaki M.M.E., 2014. Studies on the effect of salinity and seasonal changes on reproductive efficiency and growth of Tilapia (Tilapia nilotica). Ph.D thesis faculty of science. Zagazig University. 
تقييم تأثير مصادر المياه المختلفة على جودة المياه ومعدل الإعاثة ومعدل النمو ليرقات اسماك البلطى النيلى فى مفرخات اسماك البلى البلى البلى

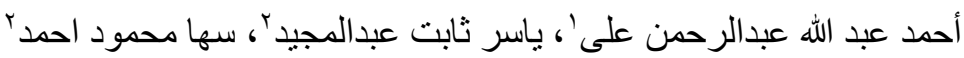

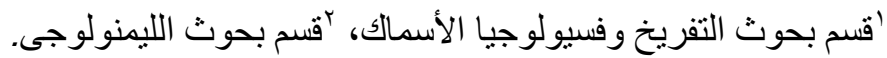

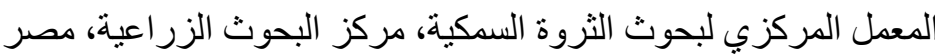

الملخص العربي

اجريت هذه الدراسة لتقييم تأثير مصادر المياه المختلفة على جودة المياه ومعدل الإعاثنة

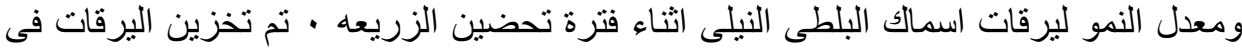

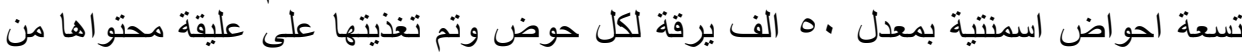

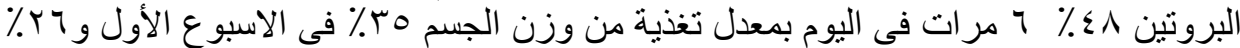

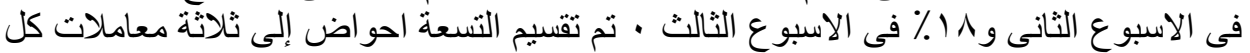

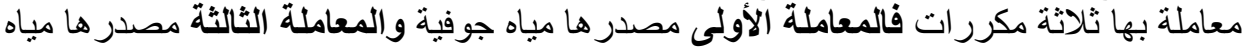

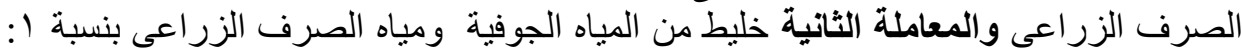

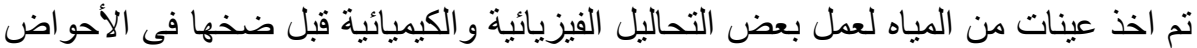

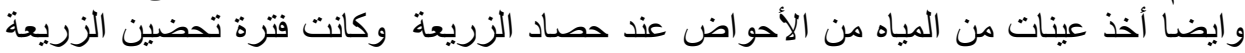

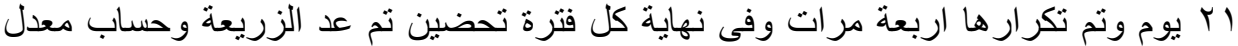

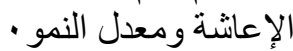

واوضحت النتائج أن أعلى معدل إعاثة ومعدل نمو للزريعة كانت مع المعاملة الثانية (مياه

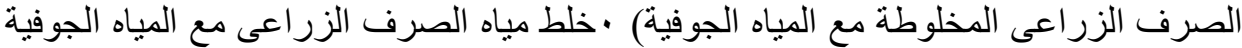

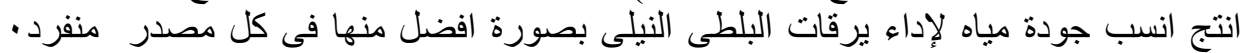
و عموما كانت معايير جودة المياه للمصادر التى نم دراستها ضمن النطاق النقان المقبول للإستزراع 